\section{Futbol Taraftarlığı Alanında Kadınları Marjinalleştiren Doxalar*}

\author{
İrem SARIKULAK ${ }^{(1+1}$, Canan KOCA (D) 1 \\ ${ }^{1}$ Hacettepe Üniversitesi, Ankara.
}

Orijinal Makale

Gönderi Tarihi: 15.10.2019
Kabul Tarihi: 13.12.2019
DOI: $10.25307 /$ jssr.633413

Online Yayın Tarihi: 31.12 .2019

$\ddot{O} \mathbf{z}$

Futbol oynamak gibi futbol taraftarlı̆̆ 1 da erkek egemenliğinde olan cinsiyetlendirilmiş bir alandır. Kadın taraftarların deneyimlerini ve alandaki konumlarını anlayabilmek, futbol taraftarlığı alanındaki genel kabul gören erkek taraftar kimliklerinden farklı taraftar kimliklerini ortaya çıkarabilmemizi ve böylelikle alanı bütünlüklü kavrayabilmemizi sağlayacaktır. $\mathrm{Bu}$ doğrultuda bu araştırmanın amacı, futbol taraftarlık alanı içerisinde kadınların konumlarını, onların marjinalleşmesine sebep olabilen doxalar yoluyla analiz etmektir. Nitel paradigmayla yürüttügümüz araştırmada spor kulüplerinin taraftarı 8 kadın ile yaptığımız bireysel görüşmelerin tematik analizi sonucunda iki tema ortaya çıktı: Eril Bir Alan Olarak Taraftarlık ve Alanın Doxası: Kabul Görmek İ̧̧in Erkek Gibi Olma. İlk temada taraftarlığın nasıl bir sosyal alan oluşturduğu ve bu sosyal alanın eril olmasını sağlayan etmenlerin neler olduğunu, ikinci temada ise kadınlardan bu eril alanda kabul görebilmek için neler beklendiğini bulgularla tartıştık. Araştırmanın sonucunda, kadınların gerçek taraftar olarak kabul edilmekte zorluklar yaşadığı, sürekli olarak futbol bilgilerinin sınandığı ve erkeklere yüklenen davranış kalıplarına uymaları ve cinsiyetçiliği kabul etmeleri halinde kabul gördükleri ortaya çıkmıştır.

Anahtar kelime: Futbol, kadın taraftarlar, Bourdieu, doxa.

\section{The Doxas that Cause the Marginalization of Women in Football Fandom}

\begin{abstract}
Like football, football fandom is a gendered field dominated by men. To understand the experience and of fans and their place in this place helps us reveal different fandom identities aside from accepted male dominant fandom identities, thus it helps to understand the field as a whole. In this aspect the aim of this study is analyzing place of the women in fandom by researcing doxas causing their marginalization. As a result of our qualitative research that include interviews held to 8 women fans of sport clubs two themes emerged. First one is Fandom as a Masculine Field, second one is Doxas of Field: To Be Like 'Men' for Accepted. In first theme we discuss how fandom creates a social field and which elements creates the masculanity of this field, in second theme we review what kind of things are expected from women to be accepted in this field. As a result of the study it reveals that women deal with hardship to get acceptance as a real fans, their knowledge is constantly questioned, and they get approval if they string along with men and accept sexism.
\end{abstract}

Keywords: Football, female fandom, Bourdieu, doxa.

*Bu çalışma 10-13 Temmuz 2019 tarihleri arasında Madrid'de gerçekleştirilen 70. IAPESGW kongresinde sözel bildiri olarak sunulmuştur.

†Sorumlu Yazar: İrem SARIKULAK, Hacettepe Üniversitesi, Spor Bilimleri Fakültesi, Eposta: iremsarikulak@gmail.com 


\section{GİRIŞ}

Futbol yalnızca Türkiye'de değil dünyada da en popüler spor dallarından bir tanesi olmakla birlikte Türkiye, futbolu en çok takip eden ülkeler arasında yer alıyor. Ancak futbolu yalnızca insanların severek izlediği bir spor olarak düşünmek pek çok şeyi gözden kaçırmak anlamına gelir. Futbol popüler bir spor dalı olmasının yanı sıra, aynı zamanda cinsiyetlendirilmiş bir alandır (Meier vd., 2017; Öztürk ve Koca, 2018). Futbolun tarihsel, kültürel ve sayısal olarak erkeklerin hakimiyetinde olması (Koca, 2012), futbolun belki de sporlar içinde doğal olarak erkeklere ait sayılan en önemli alanlardan birisi olmasını sağlamıştır (Hacısoftaoğlu, 2018). Kadınların futboldan anlamayacağına dair toplumsal ön yargılarla birlikte kadınlara futbol alanında eşit fırsatlar tanınmaması, toplumsal cinsiyet perspektifinden bir araştırma yapılmasının gerekliliğini göstermektedir.

Futbolun en önemli unsurlarından birisi taraftarlardır. Futbolun cinsiyetlendirilmiş bir alan olması taraftarlığı da etkilemiştir. Futbol taraftarlığı da erkeklerin hakimiyetine girmiş bir alan olarak kabul edilmektedir. Bu sebeple taraftarlık ve futbol konulu bilimsel araştırmaların çoğunun odak noktasını erkek taraftar oluşturmuştur (Lenneis ve Pfister, 2015; Pope, 2012). Türkiye'deki araştırmaların önemli bir bölümü de dünyada yapılan birçok araştırma gibi merkezine erkek taraftarları almıştır ve taraftarlıktaki şiddete ve holiganizme yoğunlaşmıştır (Çakmak ve Çelik, 2016; Koçer, 2012; Talimciler, 2017). Erkek taraftarlık merkezli bu tür araştırmalarda taraftarlıktaki kadınların deneyimleri göz ardı edilmiştir (Mewett ve Toffoletti, 2011). Ancak feminist perspektifle yapılan çalışmalar kadın taraftarların erkek taraftarlardan daha farklı deneyimler yaşadıklarını ortaya koymaktadır (Pitti, 2018) ve bu perspektifli araştırmaların ortaya çıkardığı en temel sonuçlardan birisi kadınların 'gerçek' taraftar olarak görülmedikleridir (Antonowicz vd., 2018). Ayrıca taraftardan güçlülük, dayanıklılık, kavga edebilme gibi özelliklerin beklenmesi ve kadınların doğal olarak güçsüz olduklarına dair toplumsal inanç kadınların taraftarlık içerisindeki hiyerarşik konumlarının altta olmasına yol açmaktadır (Pitti, 2018). Erkek taraftarlar, taraftar gruplarının liderliğini ya da yönlendiriciliğini üstlenirken kadın taraftarların ise grup içerisinde erkeklere ayak uydurması beklenmektedir.

Bourdiue'nün sosyal alan kavramıyla düşündüğümüzde futbol taraftarlığı da bir sosyal alandır ve bu alanın tarihsel bağıntıdan kopuk olmayan kendine özgü kabul görmüş değerleri (doxaları), alanın ve eyleyicilerin habitusları vardır. Bu sosyal alanın önemli eyleyicilerinden birisi kadın taraftarlardır. Kadın taraftarların alandaki deneyimlerini ve konumlarını anlayabilmek, alandaki genel kabul gören erkek taraftar kimliklerinden farklı taraftar kimliklerini ortaya çıkarabilmemizi ve böylelikle alanı bütünlüklü kavrayabilmemizi sağlayacaktır. $\mathrm{Bu}$ doğrultuda bu araştırmanın amacı, futbol taraftarlık alanı içerisinde kadınların konumlarını, onların marjinalleşmesine sebep olabilen doxalar yoluyla analiz etmektir. Araştırmanın kuramsal çerçevesini Bourdieu'nün alan kuramı oluşturmaktadır.

\section{Kuramsal Çerçeve}

Bourdiue'nun eylem kuramı bireylerin eyleyici olarak konumlandığı sosyal bağlamları incelemek için yararlı bir araç sunmaktadır (Allard, 2005). Ayrıca Dixon (2012) Bourdieu'nın eylem kuramının futbol taraftarlığının kökenleri ve onu takip eden kültürleri anlamada faydalı olduğunu belirtmektedir. Bourdieu toplumdaki iktidar ilişkilerini eylem 
kuramı ile açıklar. Bu kurama göre toplum, farklı sosyal alanlardan meydana gelir. Sanat, akademi ya da sporun her biri bir sosyal alandır. Bu sosyal alanların kendi kuralları, eyleyicileri ve işleyiş düzenleri vardır. Eyleyicilerin bu alandaki konumlarını belirleyen şey ise sermayeleridir. Sermaye birikmiş emektir (Bourdieu, 1986: 241). Bourdiue dört farkl1 sermaye biçimi tanımlar. Sosyal sermaye uzun ömürlü bir iletişim ağına sahip olmayla ilgiliyken; ekonomik sermaye maddi olanaklar, kültürel sermaye ise döneme, topluma ve sosyal sınıfa bağlı olarak bilinçsiz bir şekilde elde edilen birikimlerdir (Bourdieu, 1986). Bunların dişında her türden sermayenin alabileceği bir biçim olan sembolik sermaye ise itibar ve statü gibi kazanımlardır (Bourdieu, 2015b).

Biriktirdikleri sermayeler ile alandaki konumları belirlenen eyleyicilerin alana girmeleri için o alanı değerli kılan çıkarlarının olması gereklidir. Bu da Bourdieu'nun illusio kavramına denk gelir. Oyun metaforuyla açıkladığında illusio, Bourdieu'nun ifadesiyle oyuna girmek ve kendini oyuna kaptırmaktır (Bourdieu ve Wacquant, 2014:105). Yani illusio bir alana girmeyi değerli bulmak anlamına gelir. Doxa ise kendisini evrensel olarak dayatan bir görüş açısıdır (Bourdieu, 2015a:124). Bourdieu'ya göre eyleyiciler açıkça belli etmeseler bile alanın kuralı olduğunu varsayarlar. Bu kurallar da doxa olarak adlandırılır. Eyleyiciler bu alanda stratejiler belirlerler. Eyleyicilerin çok çeşitli durumlarla başa çıkmasını sağlayan bir strateji üretme ilkesi ise habitustur (Bourdieu ve Wacquant, 2014:27). Bourdieu habitusu yatkınlıklar olarak tanımlar. $\mathrm{Bu}$ yatkınlıklar da bireylerin toplumsal eylemlerini belirler (Bourdieu, 2015a).

Bourdieu'nun tanımından yola çıkarak futbol taraftarlığını sosyal alan olarak kabul ettiğimiz bu çalışmada, futbol alanının eyleyicileri olarak taraftarları tanımladık. Eyleyicilerin sosyal sermaye biriktirmelerini sağlayan futbol taraftarlığının kendi içerisinde kabul edilen kurallarını yani doxalarını ve bu doxaların kadın taraftarların alanda ikincil konumlanmalarındaki rollerini anlamaya çalıştık.

\section{Kadın futbol taraftarları konulu alanyazını}

Son on yılda, kadın taraftarların deneyimlerini dinlemenin önemi dünyada birçok araştırmacı tarafından anlaşılmış ve bu alanda araştırmalar yapılmaya başlanmıştır. Bu çalışmalar, araştırmanın odak noktasını erkek taraftarlardan kadın taraftarlara kaydırmış ve kadınların nasıl taraftar oldukları ve taraftarlık içerisindeki rolleri gibi konulara odaklanmıştır. Örneğin Pope, 2012 yılında yaptığı araştırmasında Giulianotti'nin (2002) taraftarlık tanımından da yararlanarak taraftarlıkta iki tip kadınlık performansı olduğunu belirtmiştir: kadınsı kadınlık ve erkeksi kadınlık. Bu alanın önemli araştırmacılarından Mewet ve Tofoletti (2011) ise kadınların dört farklı şekilde taraftar olduklarını öne sürmüş ve taraftar bir ailede doğup taraftar olanları kanında olanlar (in the blood), televizyon ya da arkadaşları aracılığıyla taraftar olanları öğrenenler (learner), bir maç izledikten sonra spora hayran olanları dönüşenler (convert) ve partnerleri ya da sevgilileri aracılığıyla taraftar olanları cinsel yolla bulaşanlar (sexually transmitted fandom) şeklinde adlandırmışlardır.

Pope ve Kirk (2014) ise İngiltere futbol takımı Leicester City taraftarı kadınlar ile yaptığı araştırmasında üç farklı jenerasyondan kadınların taraftar olmalarının okuldaki hangi fiziksel aktiviteye katılımının etkilediğini bunun yanı sıra taraftar olurken aile ve diğer faktörlerin 
rollerinin ne olduğunu araştırmışlardır. Kadın taraftarlar ile yaptıkları görüşmelerin sonucunda, kadınların okuldaki beden eğitimi dersindeki deneyimlerinin, yetişkinlik dönemindeki profesyonel futbola olan ilgilerini çoğunlukla olumsuz etkilediği sonucuna varmışlardır. Yazarlar, bu durumun en temel nedeninin kadınların futbol oynamaları için cesaretlendirilmemesi, onları oyunu oynamanın yanı sıra taraftar olmaktan da uzaklaştırmasına yol açması olduğunu belirtmişlerdir. Ancak Pope ve Kirk (2014) aynı araştırmasında bu negatif etkiye rağmen ailedeki özellikle erkek bireylerin kız çocuklarını hem spora katılım hem de taraftar olma konusunda olumlu etkilediğini de dile getirmektedir.

Sürekli olarak maça giden, takımı için koreografiler oluşturan, kendisini desteklediği takıma adamış olan taraftar grupları için adlandırılan bir Ultras grubu ile etnografik bir çalışma yürüten Pitti (2018), erkek hakimiyetinde olan ve toplumsal cinsiyet kalıplarının belirleyici olduğu bu grupta kadınların da bu önyargılara uyduğu ve buna katkı sağladığı ayrıca doğal farklılık söyleminden dolayı da kadınların Ultras grubunda esas değil yardımcı konumunda oldukları sonucuna varmıştır. Pfister ise Lenneis (2015) ile kadın taraftarların, erkeklerin ve geleneksel toplumsal cinsiyet normlarının hakimiyetinde olan taraftarlıkta bu kalıpları oluşturmak ve kırmak için neler yaptıklarını anlamak üzere Danimarka'da yaptıkları çalışmada, kadınların cinsiyetçiliğin taraftar kültürünün bir parçası olduğunu kabul ettiğini bulmuşlardır. Yazarlar, cinsiyetçiliğin kadın taraftarlarca önemsizleştirilmesinin Bourdieu'nun kavramlarından birisi olan simgesel şiddetin bir etkisi olarak yorumlanabileceğini ifade etmişlerdir. Simgesel şiddet sosyal eyleyici üzerinde kendi suç ortaklığıyla uygulanan bir şiddet biçimidir (Bourdieu ve Wacquant, 2014:166). Lenneis ve Pfister'a göre de kadın taraftarlar erkek egemenliğini kabul ederek bilinçsizce suç ortağı olmaktadır.

Türkiye'de ise kadın taraftarlarla gerçekleştirilen araştırmalar sınırlı sayıdadır. Yağmur Nuhrat ve Itır Erhart'in toplumsal cinsiyet perspektifiyle taraftarlık üzerine araştırmalar önemli bilgiler sunmaktadır. Örneğin Nuhrat 2017'deki çalışmasında, Türkiye'deki futbolda adalet kavramının cinsiyetlendirilmiş olduğunu ve evrenselleşmiş olan normlara göre farklılaştığını ortaya koymuş ve kadınların cinsiyetlendirilmiş adaletin oluşturulmasında hegemonik erkekliği yeniden ürettiğinin altını çizmiştir. Erhart ise (2013) Beşiktaş’ın kadın taraftarlarıyla bir araştırma gerçekleştirmiş ve bu taraftar grubunun Türkiye Cumhuriyeti'nin kurulmasının ardından meydana gelen sosyal, kültürel ve politik değişikliklerle ilişkilendirilmesini amaçlamıştır. Yine Erhart (2016) farklı bir makalesinde doğal farklılıklar savından türeyen kadınların kırılgan, küfürden ve soğuktan sürekli şikayet eden bir yapısının olduğu ön kabulünün taraftarlığı da çok etkilediğini ve bu doğaya karşı çıkan kadınların ise delikanlı kabul edildiğini vurgulamış ve taraftarlık içerisinde bu delikanlı kadınların kabul gördüğünü belirtmiştir. Bu gibi araştırmalar kadın taraftarlığı alanyazınına büyük katkı sağlamışlardır, fakat kadın taraftarlar konulu bilimsel bilgiler hala çok sınırlıdır.

Özetle, kadın taraftarlar konulu araştırmalar kadınların futbol taraftarlığı alanında farklı kimliklerle konumlandıklarını, ikincilleştirildiklerini ve alandaki cinsiyetçiliğin yeniden üretilmesine hizmet edebildiklerini ortaya koymaktadır. Fakat bu araştırmalarda, kadınların futbol alanındaki ikincil konumlarına etki neden futbol taraftarlığı alanına özgü faktörler yeterince analiz edilememiştir. Bu araştırmada amacımız, futbol taraftarlığını Bourdieu'nun eylem kuramı yardımıyla bir sosyal alan olarak analiz edilerek kadınların bir gruba dahil olamamak anlamına gelen marjinalleşmesine hizmet eden doxaları ortaya çıkartmaktır. 


\section{YÖNTEM}

Kadın taraftarların alanın merkezinde yer alamamalarına neden olan sorgulanmadan kabul edilen kuralları yani doxaları açığa çıkarabilmek için nitel araştırma deseni kullandık. Nitel araştırma bir bağlam içinde hayat deneyimlerine odaklanır (Tracy, 2013:5). Kadınların taraftarlık alanında marjinalleşmelerine neden olan faktörleri ortaya koyabilmek için kadın taraftarların deneyimlerini açığa çıkarmaya yarayan görüşmeler aracılığıyla bir bağlam içerisinde analiz gerçekleştirmek önemlidir. Ayrıca nitel araştırmacılar kelimelerden oluşan metinlerde gömülü olan anlamları bulmaya da odaklanırlar (Koca, 2017). Biz de bu araştırmada yaptığımız görüşmelerde kadın taraftarların kullandıkları ifadelerin ötesine geçerek bu ifadeleri Bourdieu'nun eylem kuramı çerçevesinde anlamlandırmaya çalıştık.

\section{Katılımcilar}

Bu çalışmanın araştırma grubunu belirlerken amaçlı örnekleme yöntemlerinden maksimum çeşitlilik ve kartopu örneklemesini tercih ettik. Maksimum çeşitlilik, çeşitlilikten türeyen farklı deneyimleri anlamayı kolaylaştırırken, kartopu örnekleme yöntemi ise çalışmanın ölçütlerine uyan katılımcıları kolay bir şekilde bulmayı sağlar (Merriam, 2018). Maksimum çeşitliliği belirlerken hem Türkiye'nin fazla taraftar grubuna sahip spor kulüplerinin hem de Ankara'nın bir futbol kulübünün taraftarlarını araştırmaya dahil ettik. İki Galatasaray taraftarı, iki Fenerbahçe taraftarı, bir Beşiktaş, bir Trabzonspor ve bir Gençlerbirliği kadın taraftarı araştırmaya katıldı. Araştırmamızda yer alan kadın taraftarlardan yalnızca birisi taraftar grubuna dahilken, diğer kadın görüşmeciler ise taraftar oldukları takımın herhangi bir grubuna dahil değildir. Ayrıca yine maksimum çeşitliliği sağlamak için en az bir kere futbol maçını tribünde seyretmiş olma kriterini de ekledik. Bu kriterin temel nedeni ise taraftar grupları ile beraber maç izleme tecrübesinin diğer taraftarların davranışlarını görebilmeleri için önemli olduğunu düşünmemizdir. Bu doğrultuda 24-34 yaşları arasında ve en az lisans mezunu olan 8 kadın taraftar bu çalışmanın katılımcılarını oluşturdu. Bunun yanı sıra bazı katılımcılar vasıtasıyla araştırmamıza dahil edilecek farklı kadın taraftarlara ulaşılması kartopu örneklemesine bir örnek oluşturmuştur. Katılımcıların pek çoğu çalışırken bazı katılımcılar ise evlidir. Araştırmamıza katılan iki kadın taraftar haricinde diğer tüm katılımcılar çocuk yaşlardan itibaren kendilerini taraftar olarak tanımlamaktadır.

\section{Bireysel görüşme}

Kadın taraftarlar ile yürütülen bu araştırmanın verilerini yarı yapılandırılmış bireysel görüşmeler ile topladık. Yarı yapılandırılmış görüşmeler katılımcıların algıladığı dünyayı kendi düşünceleriyle anlatmasını sağlar (Merriam, 2018: 88). Açık uçlu sorulan sorular yarı yapılandırılmış görüşmelerde katılımcılara kendi ifadeleriyle deneyimlerini anlatma firsatı tanır. Bundan dolayı görüşmelerde kadın taraftarların taraftarlık alanında yaşadıklarını kendi düşünce ve kelimeleriyle anlatabilmelerine odaklandık. 30-50 dakika arasında süren görüşmeler katılımcıların kendi belirledikleri yerlerde birinci yazar tarafından 2019 yılının Şubat-Mayıs ayları arasında yapıldı. Görüşmelerin çoğunluğu Ankara'nın çeşitli kafelerinde gerçekleştirildi. Bu çalışmaya başlamadan önce Hacettepe Üniversitesi Senatosu Etik Komisyonu'ndan da izin alındı (Sayı No: 35853172-300). Araştırmaya dahil edilen her kadına istedikleri zaman araştırmadan çekilebilme haklarının olduğu hem sözlü hem de yazılı olarak aktarıldı ve onam formu imzalatıldı. Makalede kadınların gerçek isimleri kullanılmadı. 
İlk olarak genel bilgi soruları ile başlayan görüşmelerde sorulan Bourdieu'nun kavramları ve toplumsal cinsiyet yaklaşımı temelinde hazırlanmış sorulardan bazıları ise şunlardır: Sizce taraftarlık ne anlama gelmektedir? Sizce taraftar olmanın cinsiyete göre tanımı/anlamı değişir mi? Sizce kadınların ve erkeklerin taraftar olarak kabul görmeleri için uymaları gereken davranışlar var mı? Taraftar olarak cinsiyetinizden kaynaklı herhangi bir engelle karşılaştınız mı ve bu engellerle nasıl mücadele ettiniz? Taraftar olarak yapmak istediğiniz ancak cinsiyetinizden kaynaklı yapmadığınız şeyler var mı?

\section{Veri Analizi}

Bireysel görüşmelerin analizinde kullandığımız tematik analiz verilerin içerisindeki temaları tanımlamak, analiz etmek ve raporlamak için kullanılan bir yöntemdir (Braun ve Clarke, 2008). Veri analizi yapılırken Braun, Clarke ve Weate'in tematik analiz için tarif ettiği aşamaları dikkate aldık. Braun, Clarke ve Weate (2016) tematik analizin verilere alıştırma, kodlama, tema geliştirme, iyileştirme, adlandırma ve yazma olmak üzere 6 aşamadan oluştuğunu belirtiyor. Bu aşamaları dikkate alarak ilk olarak gerçekleştirilen görüşmelerin deşifresi, daha sonrasında bu deşifreyi tekrar okuyarak satır satır kodlanması, bu kodlamanın sonunda aday temaların belirlenmesi, son aşamada ise araştırmanın kuramını da göz önünde bulundurarak nihai temaları belirlenmesi adımlarını takip ettik (Analiz sırasında kullanılan kodlamaların ve temaların örnekleri Tablo 1'de verilmiştir). Aday temalar Erkeğin Hakkı Olarak Tribün, Teste Tabi Tutulan Kadınlar, Erkeklerin Korumasındaki Kadınlar, Cinsiyetçiliğin Kabullenişi, Kabul Görmek İçin Erkekleşme ve Otokontrol Geliştime’ydi. Daha sonras bu aday temaları içerisine alan ve kuramı da kapsayan Eril Bir Alan Olarak Taraftarlık ve Alanın Doxası: Kabul Görmek için 'Erkek' Gibi Olma nihai temalarını belirledik.

Tablo 1. Tematik analiz sırasında kullanılan kodların ve temaların örnekleri

\begin{tabular}{|c|c|c|}
\hline Örnek & Kod & Tema \\
\hline $\begin{array}{l}\text { Derya: ...dedim herhalde böyle ortamlarda erkekler } \\
\text { biraz daha şey olduğu için ne dediğini bilmiyorlar. } \\
\text { Ben de onları (küfürleri) duyma pahasına gidiyorum. } \\
\text { Duyuyorum duyacağımı ama gidiyorum. }\end{array}$ & Küfrün kabullenişi & $\begin{array}{l}\text { Alanın doxası: kabul } \\
\text { görmek için 'erkek' } \\
\text { gibi olma }\end{array}$ \\
\hline $\begin{array}{l}\text { Defne: Yani normal yolda aynı kaldırımda } \\
\text { yürümeyeceğim, karşıdan geldiğinde yolumu } \\
\text { değiştireceğim adamlar tribünlerde seni böyle koruma } \\
\text { havasına giriyorlar. }\end{array}$ & $\begin{array}{l}\text { Kadınların korunması } \\
\text { gerektiği algısı }\end{array}$ & $\begin{array}{l}\text { Eril bir alan olarak } \\
\text { taraftarlık }\end{array}$ \\
\hline $\begin{array}{l}\text { Aslı: Yani kendini kabul ettirmek için biraz abilere } \\
\text { ayak uydurmak lazım. }\end{array}$ & $\begin{array}{l}\text { Tribün abilerine } \\
\text { uyma zorunluluğu }\end{array}$ & $\begin{array}{l}\text { Eril bir alan olarak } \\
\text { taraftarlık }\end{array}$ \\
\hline $\begin{array}{l}\text { Deniz: Hani kadın üzerinden yapılan futboldan } \\
\text { anlamayacağı varsayımı var. Hatırlıyorum Fenerbahçe } \\
\text { maç cezası aldığında sadece kadın taraftarlar gitti. } \\
\text { Kadın taraftarlar gittikten sonra bütün dönem } \\
\text { muhabbetler 'aman siz (kadınlar) zaten gelmeyin, siz } \\
\text { futboldan anlamazsınız' falan gibi bayağı böyle şey } \\
\text { toplu olarak } 20000 \text { kişiye karşı o ayrımcılık } \\
\text { yapıldığını çok net hatırlıyorum yani. }\end{array}$ & $\begin{array}{l}\text { Kadınların } \\
\text { ötekileştirilmesi } \\
\text { Kadınların futboldan } \\
\text { anlamadığ önyargısı }\end{array}$ & $\begin{array}{l}\text { Eril bir alan olarak } \\
\text { taraftarlık }\end{array}$ \\
\hline
\end{tabular}




\section{İnandırıcılık}

Merriam (2018:205) nitel araştırmacıların asla nesnel doğruyu ya da gerçeği yakalayamayacakları bilinen bir şey olmasına rağmen nitel araştırmacıların bulgularının inandırıcılığını arttırabilmek için kullanabileceği pek çok strateji olduğundan bahseder. Örneğin Patton (2002), araştırmada incelenen konuyla ilgili alternatif açıklamaları desteleyecek verilerin sunulmasının da inandırıcılığı arttıracağını belirtiyor (akt. Merriam, 2018). Bu doğrultuda biz de verilerin sunumunda genelin dışında kalan görüşleri ve karş1 çıkışları da kullandık. Bunlara ek olarak Tracy’nin (2010) çeşitleme stratejisini verilerin analizinde ve yorumlanmasında analizci çeşitlemesi şeklinde kullandık. Verileri ilk olarak birinci yazar analiz etmiş ardından alanın uzmanı kontrol etmiş ve görüşlerini bildirmiştir. Ayrıca, aktarılabilirliğin sağlanabilmesi için detaylı betimlemeler kullanmanın yanı sıra görüşmecilerin ifadelerine sıklıkla yer verdik.

\section{BULGULAR}

\section{Eril Bir Alan Olarak Taraftarlık}

Bourdieu'nun sosyal alan kavramı ile taraftarlığın eril bir alan olduğu yönündeki bulgulara geçmeden önce taraftarlık sosyal alanını ve habitusunu daha iyi anlayabilmek için görüşmecilerin nasıl taraftar olduklarını aktarmak önemlidir. Bu doğrultuda bu temada ilk olarak araştırmaya dahil olan kadınların nasıl taraftar olduklarını aktardık.

Görüştüğümüz kadınların futbol taraftarı olmalarının farklı nedenleri bulunsa da bazı görüşmecilerin benzer şekillerde taraftar olmaya başladıkları da dikkat çekiyor. Pek çoğu ailelerinin etkisinden dolayı taraftar olmaya başladıklarını anlatıyor: 'Bizim aile genetik Galatasaraylı. O büyü hiçbir zaman bozulmadı, damatlar dışında ... Çocukluğumdan beri gelen bir Galatasaraylı şeyi oldu' (Seda). 'Zaten Fanatik bir aileden geliyorum. Abim ve babam zaten çok fanatik' (Derya). Bazı kadın taraftarlar hangi takımın taraftarı olacakları konusunda anne ya da babalarına karşı çıksalar dahi farklı bir aile üyesinin etkisinden söz ediyorlar: 'Benim babam mesela Trabzonsporlu annem Fenerbahçeli ve böyle ikisi de fanatikler. Bizim evde maçlar her zaman izlenirdi. Kuzenim de o zaman Galatasaraylıydı. O kuzenimi rol model aldım. Onunla böyle birlikte sevinmek falan hoşuma gidiyordu' (Selin). Babasının Ankaragücü taraftarı olduğunu söyleyen Aslı ise Beşiktaş taraftarı oluşunu şöyle anlatıyor: 'Aileden gelen bir durum bu. Annem, dayım Beşiktaşlı. Aynı zamanda Anadolu Beşiktaşl1lar Derneği'nin kurucularından benim dayım. Onun vesilesiyle bütün kuzenler tabii 5-6 yaşımızdan beri Beşiktaş'ı tutuyoruz'. Bourdieu'nun temel kavramlarından birisi olan habitusu yetişme sürecinde öğrenilenler (Öztürk ve Koca, 2018) olarak değerlendirdiğimizde aileden gelen yatkınlığın taraftarların habitusları için önemli olduğunu görebiliyoruz.

Bazı katılımcılarda ise ailenin yanı sıra arkadaşların da taraftar olmada etkisi olduğu görülüyor: 'O zaman çalıştığım işyerindeki bir arkadaşım biz maçlara gidiyoruz çok güzel falan dedi. 19 Mayıs Stadyumunda oluyor dedi. Ben de, iyi bir arkadaşımdı işte, onlar giderken bir kere yanlarında gittim. Sonra tribünü çok sevdim' (Melis). Nasıl taraftar olmaya başladığını tam olarak hatırlayamadığını söyleyen Deniz ise o dönemki erkek arkadaşının ektisinin olabileceğini şöyle açıklıyor: 'Hani erkek arkadaşımın etkisi olmuştur. Ona özenip izlemişimdir ama benim de hoşuma gitti izlemek.' Araştırmaya katılan kadınların taraftar 
olma biçimleri Mewett ve Tofoletti (2011) araştırmasında kanında olanlar, öğrenenler, dönüşenler ve cinsel yolla bulaşanlar olarak tarif ettiği taraftar olma şekilleriyle benzerlik göstermesi dikkat çekici bir nokta. Ancak araştırmamızda Mewett ve Toffoletti'nin tanımladığı taraftar olma biçimlerinden farklı şekilde taraftar olan kadından da söz edebiliyoruz: 'Yani şeydi aslında esas hani futbolla ilgili olduğum için birçok maçı izliyordum fakat Fenerbahçe taraftarlığım İstanbul'da okumaya başladığımda başladı. O zaman stadyuma da giderek maç izlemeye başladım. Sonra Fenerbahçe taraftarı oldum' (Sinem). Taraftar olmadan önce de futbolu sevdiğini söyleyen Sinem'in, arkadaşlarının sevgilisinin ya da ailesinin etkisi olmadan, tribünde maç izleyerek, zaman içerisinde taraftar olması Mewett ve Toffoletti'nin (2011) tarif ettiği taraftar olma biçimlerinden farklı bir şekilde taraftar olduğunu gösteriyor.

Bourdieu'ya göre (2015c) hem yaşam tarzı hem de beğeni ve zevkler habitusu şekillendirir. Bu bakış açısıyla görüşmecilerin nasıl taraftar olduklarıyla birlikte taraftarlığın kendileri için ne ifade ettiğine baktığımızda taraftarlığın kimliklerinin bir parçası haline geldiğini görebiliyoruz: '(taraftarlık) Beni tanımlıyor. Birisi ile ilk tanıştığımızda muhabbet illaki konu ona geliyor bir şekilde. Hani bildiğim ve ilgilendiğim bir konu. Bir şekilde o konu açıldığ zaman da beni tanımlıyor' (Deniz). Aslı ise tribünde polislerden ya da çıkan kavgalardan kaynaklı yaşadığı zorluklar olsa dahi grupta kalmaya devam ettiğini ve tek sosyal aktivitesinin tribünde maç izlemek olduğunu şöyle anlatıyor: 'İyi bir aileden gelip de iyi bir çevreye sahip olduğum için insanlar tabii bu durumu yadırgıyor. Hani artık bırak bu çevreni, neden hala bu çevredesin diye. Ama dediğim gibi ben seviyorum, mutlu olduğum yerdeyim. Zaten mutlu olmasam gitmem ... Tribüncülüğü çok seviyorum (gülüyor). Tek sosyal aktivitem'.

Katılımcıların nasıl taraftar olduğu ve taraftarlığın kendileri için ne anlama geldiğini aktarmanın ardından Bourdieu'nun eylem kuramından yola çıkarak taraftarlığı sosyal bir alan olarak değerlendirdiğimizde alanın eyleyicileri olan taraftarlarla yaptığımız görüşmelerde en fazla vurgulanan konulardan birisinin grup aidiyetinin önemi olduğunu görüyoruz. Bourdiue'nun kavramlarından sosyal sermaye, alanda değerli olan bir sermaye türüdür ve bir gruba üyelikle ilgilidir (Bourdieu, 1986). Taraftarlık da bir gruba ait olma duygusunu ve davranışını yaratmasından dolayı eyleyicilerin sosyal sermaye biriktirmesini sağlar. Defne taraftarlığı tanımlarken şu ifadeleri kullanıyor: '(Taraftarlık) Aidiyet demek. Hakikaten böyle bir gruba aitsin. Herkesle aynı düşüncedesin'. Ayrıca taraftarlık normal şartlarda bir araya dahi gelemeyecek insanları buluşturuyor. Selin ve Defne belki de hiç hoşlanmayacakları normalde aynı yolda yürümeyecekleri bir insanla bile aynı takımı tutmasından dolayı yakınlık kurmalarını anlatıyorlar:

Galatasaraylı arkadaşlarla aramda sanki başka bir bă̆ varmış gibi hissediyordum. Ama mesela şey de saçma yani normalde hoşlanmadiğın bir adam ya da bir çocuk Galatasaraylı olduğu için bir anda böyle saçma bir yakınlık kurup oradan böyle başka bir ilişkiye de girebiliyordum (Selin).

Yani normal yolda aynı kaldırımda yürümeyeceğim, karşıdan geldiğinde yolumu değiştireceğim adamlar tribünlerde seni böyle koruma havasına giriyorlar (Defne). 
Bourdieu sosyal sermayeyi aynı zamanda karşılıklı tanışıklık ilişkilerinden kurulan uzun ömürlü bir networke sahip olma şeklinde tanımlıyor (Bourdieu, 2010). Taraftar olmak da taraftarlar için uzun vadeli bir iletişim ağı sunmasından dolayı sosyal sermaye biriktirilmesini sağlıyor. Deniz için taraftarlık bir sosyalleşme aracı olup ona yeni bir ortam sağlarken, Aslı için de hala görüşebildiği insanları kazanmanın bir aracı olmuştur. '(Taraftarlık) Hani bir de bir sosyalleşme aracı oldu benim için oradan insanlarla tanıştım. Yeni bir ortama girdim' (Deniz). 'Hani ben orada abileri çok seviyorum. Hala da görüşüyorum bir fiil' (Aslı).

Eyleyiciler sosyal alanda, yaşadıkları kültürler içerisinde edindikleri bilgiler ile var oluyorlar ve bu bilgiler onların alana aidiyetlerinin kurulmasının önemli bir rol oynuyor. Bu da Bourdieu'da habitus kavramına denk gelir. Her bir alan kendine özgü habituslardan oluşur. Habitus bir sınıf içerisinde bilinçsizce oluşan beğenilere ve nefret edilenlere, sevgi ve hoşnutsuzluklara, hayallere ve korkulara olan bağlılıktır (Bourdieu, 1984:77). Habitus sürekli olarak gelişen ve değişen yatkınlıklar bütünüdür (Bourdiue ve Wacqant, 2014). Bu yatkınlıklar alanın içerisindeki eylemleri de belirler. Derya abisinin normalde kendisinin yanında hiç küfür etmediğini ancak maç izlerken işlerin değiştiğini şöyle anlatıyor: 'Bir gün maç izliyoruz ... abim böyle bir küfür etti falan böyle abi dedim ne yapıyorsun yanında ben varım, kız kardeşin var, annem burada falan. Yani ne bileyim maç izliyoruz işte falan demişti. Hani yani oradan bu sonucu çıkarabiliriz; evet hani maç izlerken bu sadece futbol için değil biz futbol üzerine konuşuyoruz ama diğer sporlarda da böyle bence o küfür edilmeli yani çok basit bir şey de olsa karşılığında tepki küfür olmalı gibi bir algı var'. Önceki paragraflarda tartışıldığı gibi kadın taraftarlar normalde kabul etmeyecekleri davranışları alanın bir parçası oldukça normal olarak kabul edebiliyorlar.

Eyleyicilerin habituslarında da cinsler arası bölünmeler mevcuttur ve bu bölünmeler de toplumsal olarak doğalmış, aşikârmışçasına inşa edilmektedir (Bourdieu, 2015b: 21). Seda'nın deneyimlediği gibi futbol oynamak bir erkek yatkınlığı olarak görülüyor. Uzun süreler futbol oynadığını söyleyen Seda, ilk zamanlar futbol oynamasına ailesinin çok karşı çıktığını futbol oynamaması için kapıyı üzerine dahi kilitlediklerini ancak gizli saklı oynamaya devam ettiğini bunun da nedeninin kız olması olduğunu şu şekilde ifade ediyor: 'Erkek gibi yapım olduğu için daha çok erkekleşeceğimi düşünüyorlardı büyük bir ihtimal yani bana öyle geliyor ama daha sonrasında baktılar baş edemediler.' Futbol taraftarlı̆̆ı alanı da futboldan ayrı düşünülemeyen bir alan zira genel olarak futbol alanının eyleyicileri arasında taraftarlar da yer alıyor. Dolayısıyla, toplumda futbol taraftarlığı da bir erkek yatkınlığı olarak kabul ediliyor. Bunların yanı sıra görüşmecilerin söylediklerinden yola çıkınca gerçek birer taraftar olabilmek için korkmamanın, yeri geldiğinde kavga etmenin, küfür etmenin, bağırmanın beklendiği görülüyor. Bunlar da erkek özellikleri olarak kabul ediliyor. Lenneis ve Pfister (2015) da bağırmak, küfür etmek, bira içmek gibi geleneksel erkeksi davranışların ideal taraftar davranışları olduğunu söylüyor. Bu araştırma sonucuna benzer şekilde yeri geldiğinde bir erkekten daha çok erkek gibi olduğunu söyleyen ve bu erkeksi davranışlarından dolayı taraftar grubu içerisinde kabul görmekte herhangi bir zorluk yaşamadığını belirten Aslı erkeksi özelliklerini anlatırken şunları söylüyor:

Ben erkek gibiyim zaten o yüzden hiçbir sıkıntı yaşamadım ... Hani diyorum ya beni hep erkek Ayşe görüyorlardı ... Yeri geliyor kavga ediyorsun. Yeri geliyor daha işte dediğim gibi cesursun... Korkmuyorsun. Korkusuzsun. O stada 
girdiğinde sana polis mi müdahale etmiş biriyle kavga mı etmişsin umrunda olmuyor.

Erkek gibi olmanın kadınların taraftar olarak daha rahat bir şekilde kabul görmesini sağlaması da taraftarlığın eril bir alan olmasının önemli bir pratiğidir. Böylece tribünün hakkının erkeklere ait olduğu hem kadın hem de erkek taraftarlar tarafından kabul edilebiliyor. Aslı bu durumu neden deplasmana gitmediğini anlatırken şu şekilde açıklıyor: 'Az bilet verildiği için hani kimin hakkıysa o tribün o hakkını versin diye erkeklerin gitmesini tercih ederim...'

Cinsiyetler arası aşikarmış gibi inşa edilen bu bölünmeler tribün liderlerinin de sadece erkek olabileceği fikrini doğurabiliyor. Defne'nin de dediği gibi kadın liderler imkânsız görülüyor: 'Ben hiç böyle talepte (lider olma talebinde) bulunan bir kadını duymadım. Duysam desteklerdim ama duymadım. Ama yani sanki bu durumda bir tribün lideri mümkünatı yok (gülüyor). İmkansız ötesi bir şey bu.' Derya ise tribünde kadın liderlerin olmamasının altında yatan nedeni şöyle anlatıyor: "Bence temelinde kadın bir lider olamaz, işte kadın bir erkek topluluğu yönetemez mantığı, işte bağırtamaz, işte uygun komutu veremez gibi bir düşünce var.' Bir Gençlerbirliği taraftarı olan Melis ise tribün liderliğini babadan oğula geçen doğal bir süreç olarak tanımlıyor. Aslı ise tam tersi kadın liderlerden bahsediyor. Bu kadınlardan 'abla' olarak söz eden Aslı, kadınların grubun lideri olma çabalarını koltuk savaşı olarak nitelendiriyor: '...Ankara'da liderliği sevmiyoruz biz kadınlar. Ama İstanbul çok sever. İstanbul'da rant savaşları, koltuk sevdalısı ablalarımız çok. Ama biz onu sevmeyiz. Bizim tek amacımız zaten Beşiktaş, koltuk değil.' Aslı'nın grubun erkek liderleri olan 'abileri' için "koltuk sevdalısı" nitelemesinde bulunmaması da eril liderliği benimsediğini gösteriyor olabilir.

Araştırmaya katılan kadın taraftarların pek çoğu bu alanın bu derece eril olmasına kafa yoruyor ve bundan rahatsızlık duyuyor. Çevresinde çok fazla kadın taraftar olmasından kaynaklı algısı değiştiğini söyleyen Defne şöyle anlatıyor: 'Benim en yakın arkadaşım aşırı fanatik Fenerbahçeli. Etrafımda çok fazla kadın taraftar var. O yüzden benim algım biraz değişti. Ama tabi ki Türkiye'deki genel tanımı (taraftarlığın) eril yani. Taraftar deyince akla gelen erkek maalesef'. Taraftarlığın erilliğinden rahatsız olan bu kadınlar dahi taraftar denilince akıllarına ilk olarak erkeklerin geldiğini itiraf ediyor: ' ...futbol taraftarı dediğimiz zaman benim de hayalimde canlanan böyle kaba saba, bir sürü bağırıp çağıran küfür eden erkek grubu geliyor aklıma. Yani hiç kadın grubu gelmiyor açıkçası. Yani kadın taraftarlar biraz daha erkek taraftarların içinde var olmaya çalışıyorlar' (Selin). Taraftarlığın erkeğe ait bir alan olarak kabul edilmesi kadınların da bu alanda ikincil konumda yer almalarına ve marjinalleştirilmelerine neden olabiliyor.

Marjinal insan kavramı ilk olarak Park ile literatüre giriyor ve Park (2016), marjinal insan tipini birbirleri ile kaynaşmamış iki toplum sınırlarında duran insan olarak tanımlıyor. Ancak Park'ın yanı sıra farklı marjinallik tanımını kullanan araştırmacılar da bulunuyor. Örneğin Billson (1988) marjinalliği kültürel, sosyal ve yapısal olarak üç farklı kategoride ele alıyor ve sosyal marjinalliği bir gruba dahil olamamak ve ana akım sosyalliğin dişına düşmek şeklinde açıklıyor (s.184). Selin'in ifadesi kadın futbol taraftarlarının sosyal marjinalliğine işaret ediyor: 'Çok erkek egemen orası yani istesen de var olamıyorsun. Seni kimse çünkü ciddiye almıyor kadın taraftarsan. Bana öyle geliyor yani.' Gudykunst (1983) ise yabancı ev sahipliği ilişkisine dair 9 tipoloji sunmuş ve bunlardan bir tanesi olan marjinal insan ise davetsiz 
Sarıkulak, İ., Koca, C. (2019). Futbol taraftarlığı alanında kadınları marjinalleştiren doxalar. Spor Bilimleri Araştırmaları Dergisi, 4(2), 246-263.

misafir, aradaki azınlık gibi ev sahibi gruba üye olmaya çabalayan ancak düşmanca karşılanan kişiler olarak tanımlamıştır (Hülür, Ekinci ve Deniz, 2017). Defne'nin aşağıdaki alıntısından anlaş1lıyor ki taraftar grubunda da ev sahibi konumunda erkekler kabul edilebiliyor ve kadınlar da bu alanın misafirleri görülebiliyor:

Orası (futbol taraftarlı̆̆l) onların (erkeklerin) alanı zaten öyle hissediyorlar. Yani böyle hissetmeyen biziz. Orası erkek alanı, sahibi olarak gidiyorlar. Biz misafir olarak gidiyoruz. Ev sahibi kurallarına uymak zorundayı gibi bir durum var (gülüyor) (Defne).

Taraftarlıkta erkeklerin egemen olması kadınları erkeklerin koruması altında olması durumunu doğurabiliyor. Taraftar gruplarının 'abileri' kadınları kendi korumaları altında görebiliyor; '(Maçlara giderken yoluculuklar sırasında) Çarşı Ankara olarak hiçbir sıkıntı yaşamıyorduk yani abiler de koruyorlardı daha doğrusu kızları.” (Aslı) Görüştüğümüz kadın taraftarlara göre bu korumayı bir adım ileri taşıyıp tribündeki kadınları namusu olarak gören erkekler de olabiliyor. Erkek taraftarlar kendilerini aynı takımı tuttukları fakat hiç tanımadıkları kadın taraftarların koruyucuları konumuna yerleştirebiliyor. Defne bir kafede maç izlediği sırada küfür eden rakip takım taraftarına tepki göstermesinin ardından kendisi ile aynı takımı tutan diğer erkeklerin kendisini korumaya çalıştıklarını şöyle anlatıyor: 'Normalde ben Fenerbahçeli olsam Galatasaraylılar bana küfrederdi. Fenerbahçeliler bana küfrettiği için ve ben Galatasaraylı olduğum için o diğer Galatasaraylı erkekler de direk namus koruma moduna giriyorlar yani bizim bacimiza ne diyon falan moduna giriyorlar. Tanımam etmem hâlbuki (gülüyor).' Benzer bir durum yaşayan Sinem de yine erkek taraftarların kendisini korumaya çalıştı̆̆ını ancak bu duruma karşı çıktığını söylüyor:

Benim kombinem vardl İstanbul'dayken. Normalde iki üç kişi işte ablam eniştem falan birlikte gidiyorduk. Sonra tek gittiğim bir maçta bir grup erkek holigan, taraftarlardan benim olduğum koltuğu da kapatarak ayakta maç izliyorlar, maçı destekliyorlar. Sonra işte burası benim koltuğum dedim. Abla işte bir şey olursa biz sana yardımcı oluruz filan böyle hani orası erkek alanı ve bir kadının gelmesi sanki çok anormal bir durummuş gibi benim güvenliğim onlardan sorumluymuş gibi böyle benim bir koruma kollama şeyine girdiler. Ben de yani benim burada sizin korumaniza ihtiyacım yok dedim. Benim koltuğum burası, buradan uzaklaşırsanız en iyisini yaparsınız dedim.

Futbol taraftarlığı alanının futbol yatkınlığı ve futbol bilgisi içeren habitusu, tarihsel ve kültürel olarak futbol ve erkeklik ilişkisi bağlamında inşa ediliyor. Bu habitus alandaki pratikler aracılığıyla alanın eyleyicileri tarafından inşa ediliyor. Görüştüğümüz kadın taraftarlar, erkekler tarafından futbol bilgilerinin ve ilgilerinin sürekli sorgulandığını, yani erkekler tarafından teste tabii tutulduklarını belirtiyorlar. Selin, erkeklere kendisini kanıtlamak ve erkeklerden onay almak durumunda kalmasını anlatıyor:

Yani bir taraftarsan da kanitlamaya çalışıyorsun ya ben de sizin kadar anllyorum. Yani ben de futboldan anliyorum, ben de işte pozisyonlarl biliyorum. Ofsayt nedir biliyorum, out taç nedir biliyorum. İşte hakemin şu kartı bu bayră̆ söyle kaldırması ne demek biliyorum. Yani benim de futbol bilgim var, hani ben de takip ediyorum, ben de futboldan anllyorum ve benim 
de maça gitmek hoşuma gidiyor. Ne bileyim bă̆ırmak hoşuma gidiyor ya da hani canlı canlı gol olduğunu görmek vesaire hoşuma gidiyor. Ama böyle bir kadınların kendini kanitlama durumu oluyor erkek taraftarlara karşı yani benim öyleydi. Böyle hep şeydi ve kanitlamaktan ziyade bir de onların onayın almaya çalışıyorsun. Hani öyle hissediyordum. Hani nasıl desem böyle maç izliyordum ve gerçekten izlediğimi ve anladı̆̆ımı göstermek istiyordum.

Deniz’e göre futboldan anlayan kadın ise erkekler tarafından şaşılacak bir şey olarak kabul ediliyor, kadın ile taraftarlık birbirleri ile örtüşmeyen şeyler olarak düşünülüyor: 'Futbolla ilgilenen kızın hemen anında 'aa biliyor musun? Hakikaten mi?' Kız ve futbolla ilgilenen taraftar olmak bağdaştırılamıyor. Hatta 'oha maça $\mathrm{m}$ i gidiyorsun?' falan tepkilerini alıyorum'. Ayrıca, görüştüğümüz kadınlara göre kadınların tek başlarına taraftar olabileceklerine çoğu erkek taraftar inanmıyor. Kadının taraftar olması için bir erkeğin etkisi olması gerektiği düşünülüyor. Bundan dolayı kadın taraftarlar teste tabi kılınmalarının yanı sıra taraftar olmasında etkili olan bir baba, erkek kardeş ya da erkek arkadaş sorgusuna da maruz kalıyor: 'Baban Galatasaraylıydı ondan mı Galatasaraylısın... Yani nasıl diyim annem Galatasaraylıydı ondan Galatasaraylı oldum desem kabul edilmez. Peki baban hangi takımlıydı? Yani bu sorulacak.' (Defne). Tek başına deplasman maçına giden Melis ise maçlara gecekondu bölgesinden gelen oğlan çocuklarının bu duruma şaşırdıklarını şu şekilde anlatıyor: 'Aa abla sen sevgilisi olmadan gelen tek insansın. Hani senin sevgilin olmadığ1 halde kalkıp geliyorsun deplasmana.'

Akbaş (2012), sosyal medyada futbol taraftarlarının erkeklik söylemi üzerine yaptığ çalışmasında futbolun, taraftarların da katkısıyla basit bir spor aktivitesi olmaktan öteye geçip kadınları ve kadınsılığı dışlayan, öteki erkekliklere kapalı olan eril bir eğlence kültürüne dönüştüğünün gözden kaçırılmaması gerektiğini vurguluyor. Talimciler'de (2017) yine benzer şekilde taraftarlıkta erkeklikle ilintilendirilen şiddet, homofobi, küfür/argo kullanımı gibi davranışların fazlasıyla görüldüğünü söylüyor. Zimbabve taraftarları ile araştırma yapan ve özellikle marşlara odaklanan Ncube ve Chawana'da (2018) Çin'deki Arsenal taraftarları ile araştırma yapan Gong' da (2016) taraftarlık ile erillik arasında bağ olduğunu ortaya koyuyor. Türkiye'de ve dünyada taraftarlık konulu yapılan araştırmaların pek çoğunda olduğu gibi bizim araştırmamız da taraftarlığın eril bir alan olarak kabul edildiğini ortaya koyuyor. Bu araştırmalardan farklı olarak biz, taraftarlığın eril bir alan olmasını sağlayan faktörleri ve bu etmenlerin kadınları nasıl marjinal bir konuma koyduğunu da inceledik. Bourdieu'nun eylem kuramından yola çıkarak taraftarlık sosyal alanınındaki habitusun, eyleyicilerin pratikleri ile hem tarihsel hem de kültürel olarak inşa edildiği sonucuna vardık. $\mathrm{Bu}$ inşa sonucu futbolun erkek yatkınlığı kabul edilmesi kadınların da bu alanın ötekileri olmalarına sebebiyet veriyor. Bir sonraki temada ise taraftarlık alanında kadınların ötekileştirilmesine yol açan doxaların neler olduğunu tartıştık.

\section{Alanın Doxası: Kabul Görmek için 'Erkek' Gibi Olma}

Bourdieu sorgulanmadan kabul edilen kurallar olarak doxayı tanımlar. Eyleyiciler açıkça ifade etmeseler bile alanın kuralları olduğunu kabul ederler ve bu kurallara da uyarak doxaları yeniden üretirler. Doxa, özel bir görüş açısıdır, kendini evrensel olarak dayatan bir görüş açısı, egemen olanların görüş açısıdır (Bourdieu, 2015a:124). Görüştüğümüz kadınlara göre, futbol taraftarlığının erkek alanı olarak görülmesinden dolayı bu alanda var olabilmek 
ve kabul görebilmek için erkeklerin kurallarının benimsenmesi, başka bir ifadeyle 'erkekleşme' zorunluluğu gerekiyor: 'Ya zaten stada girdiğinde yani erkekleşmek zorundasın.' (Defne), 'Bazı kadınlarda bir erkekleşme şeyi, bir erkek gibi tepki verme, küfür etme şeyleri de görüyordum.' (Melis). 'Erkek gibi' kadın taraftarlar gerçek taraftar olarak kabul edilirken 'kadınsılığı'nı bırakmayan kişiler ise 'gerçek' taraftar olarak değerlendirilmiyor: 'Yani erkek gibi olması tabii ki gerekmiyor. Bir sürü kız var böyle hani benim gibi olmayıp da gayet cicili bicili gidip de maç izleyen. Ama çok kâle almiyor erkekler öyle kızların tribüncülük anlayışlarını.' (Asl1). Sveinson ve Hoeber'in (2016), Basketbol, Hokey, Amerikan Futbolu ve Beyzbol taraftarı kadınlar ile yürüttüğü araştırmada da benzer olarak kadın taraftarların aşırı kadınsı olsalar erkek taraftarlar tarafından ciddiye alınmayacaklarını vurgulamaktadır. Özellikle tribünün içerisinde kabul görmek için bu erkekleşme gerekliliği oldukça ağır basıyor. Tribün erkeklerin alanı olarak görülmesinden dolayı bu alanda maç seyretmek için 'erkek gibi' maç izlenmesi bekleniyor: 'Hani böyle süslenip püslenip giden kadınlardan pek haz etmiyorum ... Ben çok tasvip etmiyorum bunu. Süslenip püslenip gideyim maça o şekilde destekleyim. Benim giydiğim kıyafetler bile aynıdır. Yani maça giderken hiç değişmez, hiç şey yapmam. Benim zihniyetim bu yani erkek gibi gideceğim geri de döneceğim yani.' (Aslı). Yine aynı şekilde Sveinson ve Hoeber'in (2016), kadınların spor izlerken ya da tartışırken daha erkeksi oldukları bulgusu bizim araştırmamızda futbol taraftarları için de geçerli olduğunu görüyoruz. Defne ise tribünde maç izleyen kadından beklenenlerin şunlar olduğunu söylüyor: 'Küfürden rahatsız olamamak gerek. Ondan sonra orda kalabalığa girmekten çekinmemek gerek. Korkamamak gerek.' Nelerden korkmamak sorusunu Defne şöyle yanıtliyor: 'taciz korkusu, yani sürekli yaşadığımız 7/24 dolmuşa binerken, taksiye binerken yaşadığımız korku. Onu yaşamamanı beklerler (erkekler). Rahatsız oluyorsan gelme derler (erkekler).'

Geçmiş yıllarda yapılan araştırmalar da 'erkek gibi' olan kadın taraftarların taraftarlık içerisinde daha ciddiye alındığını ortaya koymuştur. Örneğin Giulianotti’nin (2002) taraftar tanımları ile Ussher'ın (1997) tarif ettiği kadınlık performanslarını birleştiren Pope (2012), kadın taraftarlar için erkeksi kadınlık ve kadınsı kadınlık olmak üzere iki tür performans olduğunu belirtmiştir. Pope, erkeksi kadınlık olarak tanımladığı performansı gençken 'erkek Fatma' olarak kabul edilen, daha önceden takım sporlarına dahil olmuş, güçlü bir şekilde kendisini erkek taraftarlar ile özdeşleştiren kadın taraftar olarak tarif ediyor. Bunun tam tersi olan kadınsı kadınlık performansı ise sporu aileleri ile vakit geçirmek için bir firsat olarak gören kadınlar için Pope tarafından tanımlanmıştır. Bizim araştırmamızdaki görüşmecilerin bahsettiği erkek gibi kadın taraftarlar Pope'un erkeksi kadınlık performansına denk gösterilebilir. Pope araştırmasına ek olarak kadınların bu performansı sergilemelerinin nedeni olarak bu şekilde kabul göreceklerine inanmaları olduğunu söyleyebiliriz. Görüştügümüz Selin de ortaokul yıllarında yaşıtları erkek taraftarların kendisini gerçek bir taraftar olarak kabul ettiğini şöyle anlatıyor: 'Hani böyle onların (erkek) erkek muhabbetine girebiliyordum ve hani bana böyle şey diyorlardı 'ya Selin zaten hani bizden biri, ya bizden sayılır sorun olmaz' falan diyorlardı. Yani çünkü bir şekilde sanki onların dilini ayak uyduruyor gibiydim.' Aslı ise taraftar grubunda kabul görmesini erkek gibi olmasına bağlarken şunları söylüyor: 'Hani bazı erkekler de var tribün erkek işidir. Bırakın onlar yapsın diye ama ben yeri geliyor bazı erkekten de erkek olabiliyorum.'

Erkekleşerek taraftar olma durumundan rahatsız olan ve karşı çıkan kadın taraftarlar da mevcuttur: 'Onların (erkeklerin) tepkilerinin aynısını yapmaya çalışıyoruz. Yani ben aslında 
Sarıkulak, İ., Koca, C. (2019). Futbol taraftarlığı alanında kadınları marjinalleştiren doxalar. Spor Bilimleri Araştırmaları Dergisi, 4(2), 246-263.

buna gerçekten heyecanlanmıştım. O farklılıkla anıldığımı düşündüğüm kendimce şey de ben sizin gibi böğürerek sevinmek istemiyorum. Melis nasıl sevinirse öyle sevinmek istiyorum. Bunun mesela şey yapmak isterdim yaymak ya da duyurmak ama hiç öyle bir imkânım olmadı.' (Melis). Erkeklere ayak uydurma kadın taraftarların cinsiyetçi olmalarına yol açabiliyor. Deniz tribünde küfür eden kadınlardan bahsederken şu ifadeleri kullanıyor:

...onlar (kadınlar) birazcık böyle nasıl diyeyim seksist olmadan nasıl söyleyebileceğimi bilmiyorum ama böyle oraya ayak uydurmaya çalışlyorlar ama olmuyor pek. Çünkü dediğim gibi çok fazla erkek hegemonyası var ve hani bunları kırmaya çalışmıyorlar onlardan biri oluyorlar. Onlar (kadınlar) onlardan (erkeklerden) daha çok sexist olmaya başliyorlar, onlar onlardan daha çok erkek dili konuşmaya başllyorlar ve bir anda onların içinde kendilerini eritiyorlar.

Görüştüğümüz bazı kadın taraftarlar cinsiyetçi söylemlerden ve küfürlerden rahatsız olduklarını ve buna tepki gösterdiklerini de belirtiyor. Derya küfür eden bir erkek taraftara verdiği tepkiyi ve karşılığında aldığı cevabı şöyle anlatıyor: 'Hani beyefendi dedim. Biz burada maç izlemeye çalışıyoruz ama siz çok yüksek sesle ve ağza alınmayacak şeyler söylüyorsunuz. 'İstemiyorsan, duymak istemiyorsan bunları gelme' diye bir tepki aldık. Birazcık üzdü yani, hani böyle bir tepki beklemiyordum. Böyle bir tepki alınca dedim herhalde böyle ortamlarda erkekler biraz daha şey olduğu için ne dediğini bilmiyorlar.' Son dönemde küfürden rahatsız olan ancak geçmişte bundan bir rahatsızlık duymadığını belirten Defne bunun nedenini rahatsız edilmeden maç izleyebilmek ve kabul görmek olarak açıklıyor:

Ben de öyleydim yani hani küfür edilince, statta küfredildiğinde rahatsız olmazdım. Daha doğrusu şöyle bir şey olurdu, rahatsız olurdum ama rahatsız değilmişim gibi davranırdım. Ve öyle davranmak beni rahatsı etmiyordu. Ya ben niye böyle davranıyordum diye sorgulamıyordum. Hani onlar da (diğer kadın taraftarlarda) da öyle olabilir. Kabul görmek istiyorsun yani hani sevdiğin bir şeyi yapıyorsun. Taraftarsın. Maç izliyorsun zevk alıyorsun. Orda bulunmaktan çok hoşlanıyorsun. Ne bileyim bir dünya yol gitmişsin falan yani çile çekmişsin o stada girene kadar ve haliyle orda olmaktan mutlu olmak istiyorsun. Ve rahatsı değilmiş gibi davranıyorsun. Ya o aidiyet büyük bir motivasyon bence. Kadınlarda da bu olabilir. Kesin bir şey söylemiyorum ama bendeki bence buydu yani orda rahatsı olmak istemiyordum. Hiç istemedim orda rahatsiz hissetmek.

Böyle bir duruma tepkisizleşmeyen ve rahatsılık duymaya devam eden kişiler ise taraftarlıktan yavaş yavaş uzaklaşıyor. Selin taraftarlıktan uzaklaşmasını '...Ne bileyim sinirlenmelere, küfür etmelere filan böyle bir normalleştirilmiştim. Anladığım kadarıyla rahatsız etmiyordu sanırım. Yani ne zaman ki beni rahatsız etmeye başladı taraftarlıktan çıkıp onun böyle saçma sapan bir şey olduğunu o zaman farkına vardım.' şeklinde anlatıyor. Ancak taraftar olmaktan uzaklaşmak istemeyen kadınlar da bulunuyor. Taraftar olmaktan vazgeçmeyen ve taraftarlıktan uzaklaşmak istemeyen kadınlar ise bazı otokontrol mekanizmaları geliştiriyor. Kadın taraftarlar özellikle derbi maçlarında kavga çıkma ihtimalinin yüksek olmasından dolayı maçları evlerinde izlemeyi tercih ediyor. Bunun yanı sıra deplasman maçlarına gidiş sırasında yaşanabilecek sorunlar nedeniyle kendisini fanatik 
Sarıkulak, İ., Koca, C. (2019). Futbol taraftarlığı alanında kadınları marjinalleştiren doxalar. Spor Bilimleri Araştırmaları Dergisi, 4(2), 246-263.

bir taraftar olarak adlandıran kadınlar dahi deplasman maçlarına gitmiyor. Aslı deplasmana gitmediğini erkek olsa kesin gitmek istediğini şu sözleriyle dile getiriyor:

Erkek olsam kesin giderdim. Ama kı olduğum için çok göze alamadım. Göze alabileceğim bir şey değil. Yani tek kızsın, otobüste 50 tane erkek var ve dağın başında bir yere gidiyorsun. Yani göze alabileceğim bir şey değildi. O yüzden hani keşke erkek olup da deplasmana gidebilseydim. Hayattaki tek keşkem tribüncülükte bu.

Bourdieu'ya (1997) göre doxa, eyleyiciye alana ait olma duygusu veren ve alanın işleyiş tarzını doğal gösteren ön kabullerdir (akt. Koytak, 2012). Araştırmamızın bulguları geleneksel olarak 'erkeksi' olarak kabul edilen küfür etme, kavga etme, korkusuz olma gibi davranışların taraftarlık içerisinde kabul gördüğünü ve bu davranışların kadınlar tarafından da taraftarlığın doğası olarak sorgulanmadan kabul edilmesinden dolayı doxa olarak gösterilebileceğini ortaya koymuştur. Erhart (2016), maçlara makyajsız giden, küfreden, meşale yakan, sahaya inmeye çalışan bu kadın taraftarları delikanlı kadın taraftar olarak tanımlıyor. Biz ise araştırmamızda bu davranışların birer doxa olduğunu savunuyoruz. Kadın taraftarların bu ön kabullere uyarak doxaları yeniden ürettiğini de söyleyebiliriz. Ancak bu durum her kadın taraftar için geçerli değildir. Bu doxalardan rahatsız olan Selin gibi kadın taraftarların da taraftar gruplarından kopabildiğini görebiliyoruz.

\section{TARTIŞMA VE SONUÇ}

Kadınların futbol taraftarlığ yaptığımız bu araştırmada, Bourdieu'nun eylem kuramından yola çıkarak futbol taraftarlığını bir sosyal alan, taraftarları da eyleyiciler olarak değerlendirdik. Kadın taraftarlarla yapılan geçmiş araştırmalara benzer olarak bu çalışmada da taraftarlığın hala erkeklerin hakimiyetinde olan bir alan olduğu sonucuna vardık. Bu çalışmanın ortaya koyduğu bir diğer nokta ise taraftarlık içerisinde kadınların erkekler ile eşit konumda yer alamadığ 1 ve erkekler kadar gerçek birer taraftar olarak kabul görmekte zorluk çektikleridir. Lenneis ve Pfister'in da (2015) çalışmalarında belirttiği gibi bağırmak, küfür etmek gibi geleneksel erkeksi davranışlar olarak görülen tutumlar ideal taraftar davranışları olarak kabul ediliyor. Kadınlar ise bu alanda gerçek taraftar olarak kabul görebilmek için bu 'erkeksi' davranışlar göstermeleri gerektiğini düşünüyorlar. Bourdieu, eril hakimiyetin bireylerin alışkanlıklarına yerleşen ve yeniden üreten sosyal dünyanın nesnel yapılarında nasıl doğal bir hal kazandığını göstermektedir (McNay, 2000). Cinsiyetçilik de taraftarlığın özünde olan doğal bir durum olarak kabul edilmektedir. 'Erkek gibi' davranan ve cinsiyetçi söylem ya da küfürleri sarf eden kadın taraftarlar daha iyi taraftar olarak değerlendiriliyor. Bunu kabul etmeyen kadınlar ise taraftarlıktan yavaş yavaş uzaklaşıyor ya da bu tür davranışlara maruz kalmamak için kendilerini korumak adına bazı otokontrol yöntemleri geliştiriyor. $\mathrm{Bu}$ otokontrol yöntemlerinden de en önemlisi olarak deplasmana gitmemek ve derbi maçlarını topluluktan uzak bir şekilde evlerinde seyretmek gösterilebilir. Gerçek taraftar olabilmek için korkusuz olmak, küfür etmek, kavga edebilmek gibi özellikler bekleniyor. Bu özelliklerin de erkeklere atfedilmesi ve kadınların doğal olarak kırılgan, narin olduğu ve bundan dolayı kadınların taraftarlığa uygun olmadığının sorgulanmadan kabul edilmesi Bourdieu'nun doxa kavramına 
denk geliyor. Bu doxalar da kadınların futbol taraftarlığı alanında marjinalleşmesini sağlıyor. Taraftarlığa atfedilen bu özellikleri benimseyerek de pek çok taraftar bu doxaları yeniden üretiyor.

Daha önceki taraftar konulu araştırmaların pek çoğunda olduğu gibi bizim çalışmamızın verileri de taraftarlığın eril bir alan olduğunu ortaya koymuştur (Lenneis ve Pfister, 2015; Pitti, 2018; Toffoletti, 2012). Ancak daha önceden futbol taraftarları konulu araştırmalardan farklı olarak biz bu araştırmamızda taraftarlık alanını eril yapan faktörlerin neler olduğunu ve kadınları bu alanın ikincil konumuna iten doxaların neler olduğunu irdeledik. Ayrıca taraftarlık için atfedilen davranışları ve düşünce pratiklerini benimseyen kadın taraftar olduğu gibi bunlara karşı çıkan kadınlar olduğunu da gördük. Buna güzel bir örnek olarak kadınların taraftarlık içerisinde özellikle tribünde erkek taraftarlar tarafından korunması gerektiği fikrine karşı çıkan Sinem gösterilebilir.

Bu araştırma yalnızca Türkiye'nin büyük kulüplerinin kadın taraftarları ile gerçekleştirildi. Ayrıca araştırmaya dahil edilecek taraftar grupları belirlenirken İstanbul dışında yalnızca Ankara ve Trabzon takımlarını tercih ettik. Bunun da nedeni bu ekiplerin köklü kulüpler olmasının yanı sıra Türkiye futbolunun büyük kulüpleri olarak da kabul ediliyor olmasıydı. Ayrıca Süper Lig ekiplerinin dışında kalan alt liglerdeki takımların taraftar grupları bizim araştırmamızın dışında kaldı. Bu da yalnızca çok daha göz önünde olan futbol takımlarının taraftar gruplarına yoğunlaşmamıza neden oldu. Daha küçük takımların taraftar gruplarında kadınların ikincil konumda kalmasını sağlayan farklı doxalar varsa bu araştırmamıza dahil olamadı. Ayrıca bizim araştırmamızda kadın taraftar gruplarında yer alan kişiler de bulunmuyor. Takımların kadın taraftarlar grupları ile yapılacak olan farklı bir çalışma bizim araştırmamızdan farklı sonuçlar ortaya koyabilir. Özellikle böyle bir araştırma doxaların yeniden üretilmesinin dışında bu doxalara karşı çıkışları da bize sunabilir. Bu yüzden gelecek dönemde futbol takımlarının kadın taraftar grupları ile gerçekleştirilecek bir araştırma kadın futbol taraftarlığı alan yazını için büyük katkı sunacaktır.

\section{KAYNAKLAR}

Akbaş, E. (2012). Türkiye'de sosyal medyada futbol taraftarlarının erkeklik söylemleri. Yayımlanmış Yüksek Lisans tezi, İstanbul Bilgi Üniversitesi, Sosyal Bilimler Enstitüsü, Medya ve iletişim Sistemleri Yüksek Lisans Programı, İstanbul.

Allard, A. C. (2005). Capitalizing on Bourdieu: How useful are concepts of 'social capital'and 'social field'for researching 'marginalized'young women?. Theory and Research in Education, 3(1), 63-79. DOI: $10.1177 / 1477878505049835$.

Billson, J. M. (1988). No owner of soil: The concept of marginality revisited on its sixtieth birthday. International Review Of Modern Sociology, 18(2)183-204. [Erişim Adresi: https://www.jstor.org/stable/41420931].

Bourdieu, P. (1997). Méditations pascaliennes. Paris: Seuil.

Bourdieu, P. (2010). Sermaye biçimleri. (Der. M.M Şahin ve A.Z Ünal) Sosyal Sermaye. İstanbul: Değişim, 4575.

Bourdieu, P. (2015a). Pratik nedenler. Çev.: Hülya Uğur Tanrı̈ver. İstanbul: Hil Yayın. 
Sarıkulak, İ., Koca, C. (2019). Futbol taraftarlığı alanında kadınları marjinalleştiren doxalar. Spor Bilimleri Araştırmaları Dergisi, 4(2), 246-263.

Bourdieu, P. (2015b). Eril tahakküm. Çev.: Bediz Yılmaz. İstanbul: Bağlam.

Bourdieu, P. (2015c). Ayrım: Beğeni yargısının toplumsal eleştirisi. Çev.: Derya Fırat, Günce Berkkurt, Ankara: Heretik Basın Yayın.

Braun, V., \& Clarke, V. (2006). Using thematic analysis in psychology. Qualitative Research In Psychology, 3(2), 77-101. DOI: 10.1191/1478088706qp063oa.

Braun, V., Clarke, V., \& Weate, P. (2016). Using thematic analysis in sport and exercise research. (Ed: B. Smith, A.C. Sparkers). In Routledge handbook of qualitative research in sport and exercise. 213-227. Routledge. DOI: 10.4324/9781315762012.ch15.

Çakmak, M., ve Çelik, V. (2016). Futbolda şiddet ve erkeklik: Nefer taraftar grubu örneği. Istanbul Journal of Sociological Studies, 54 (2016-2), 299-331.

Dixon, K. (2013). Learning the game: Football fandom culture and the origins of practice. International Review for the Sociology of Sport, 48(3), 334-348. DOI: 10.1177/1012690212441157.

Ekinci, Y., Hülür, A. B., ve Deniz, A. Ç. (2017). Yabancı ve marjinal olarak öteki: yerleşik ve yabancı ilişkisi bağlamında suriyeli sığınmacılar. Tarih Okulu Dergisi, $10(\mathrm{XXX}), 365-392$. DOI: 10.14225/Joh1099.

Erhart, I. (2013). Ladies of Besiktas: A dismantling of male hegemony at Inönü Stadium. International Review for the Sociology of Sport, 48(1), 83-98. DOI: 10.1177/1012690211427986.

Erhart, I. (2016). Kadınlar ofsayttan anlar mı? Tarihi karar, kadın taraftarlar ve etiketler. C. Koca (Ed.) Sporun Toplumsal Cinsiyet Halleri içinde (184-200). Ankara: Spor Yayınevi.

Giulianotti, R. (2002). Supporters, followers, fans, and flâneurs. Journal of Sport and Social Issues, 26(1), 2546. DOI: $10.1177 / 0193723502261003$.

Gong, Y. (2016). Online discourse of masculinities in transnational football fandom: chinese arsenal fans' talk around 'gaofushuai' and 'diaosi'. Discourse \& Society, 27(1), 20-37. DOI: $10.1177 / 0957926515605964$.

Gudykunst, W. B. (1983). Toward a typology of stranger-host relationship. International Journal of Intercultural Relations, 7(4), 401-413. DOI: 10.1016/0147-1767(83)90046-9.

Hacısoftaoğlu, İ. (2018). Futbolda erkekliğin gür sesi: taraftarlığın cinsiyetle olan ilişkisi nedir?. The Blizzard Dergisi, 1, 111-122.

Koca, C. (2006). Beden eğitimi ve spor alanında toplumsal cinsiyet ilişkileri (derleme). Hacettepe Spor Bilimleri Dergisi, 17(2), 81-99.

Koca, C. (2012). Sporda sosyokültürel boyutlar. H. Ertan (Ed.). Spor Bilimlerine Giriş içinde. Eskişehir: Açık Öğretim Fakültesi, Anadolu Üniversitesi Yayınları.

Koçer, M. (2012). Futbol derneklerine üye olan taraftarların şiddet ve holiganizm eğilimlerinin belirlenmesi: Kayseri örneği. Erciyes Üniversitesi Sosyal Bilimler Enstitüsü Dergisi, 1(32), 111-135.

Koytak, E. (2012). Tahakküme hükmetmek: Bourdieu sosyolojisinde toplum ve bilim ilişkisi. İstanbul Üniversitesi Sosyoloji Dergisi, 3(25), 85-101.

Lenneis, V., \& Pfister, G. (2015). Gender constructions and negotiations of female football fans. A case study in Denmark. European Journal for Sport and Society, 12(2), 157-185. DOI: 10.1080/16138171.2015.11687961.

McNay, L. (2000). Gender and agency: Reconfiguring the subject in feminist and social theory. Cambridge: Polity Press.

Meier, H. E., Strauss, B., \& Riedl, D. (2017). Feminization of sport audiences and fans? Evidence from the German men's national soccer team. International Review for the Sociology of Sport, 52(6), 712733. DOI: $10.1177 / 1012690215612457$. 
Sarıkulak, İ., Koca, C. (2019). Futbol taraftarlığı alanında kadınları marjinalleştiren doxalar. Spor Bilimleri Araştırmaları Dergisi, 4(2), 246-263.

Merriam, S.B. (2018). Nitel araştırma: Desen ve uygulama için bir rehber. Ankara: Nobel Akademik Yayıncilik.

Mewett, P., \& Toffoletti, K. (2011). Finding footy: Female fan socialization and Australian rules football. Sport In Society, 14(5), 670-684. DOI: 10.1080/17430437.2011.575112.

Ncube, L., \& Chawana, F. (2018). What is in a song? Constructions of hegemonic masculinity by Zimbabwean football fans. Muziki, 15(1), 68-88. DOI: 10.1080/18125980.2018.1503560.

Nuhrat, Y. (2017). "Fair to Swear?" Gendered formulations of fairness in football in Turkey." Journal of Middle East Women's Studies, 13(1), 25-46. DOI: 10.1215/15525864-3728624.

Öztürk, P., ve Koca, C. (2018). Futbolda kadınlar: Bir sosyal alan olarak kadın futbol takımının analizi. Turkiye Klinikleri Spor Bilimleri, 10(3),150-163. DOI: 10.5336/sportsci.2018-61162.

Park, R. E. (2016). İnsan göçü ve marjinal insan. L.Ünsaldı (Ed.), Çev.: Kübra Eren. Yabancl: Bir İlişki Biçimi Olarak Ötekilik içinde (69-82). Ankara: Heretik Yayınları.

Patton, M. Q. (2002). Qualitative research and evaluation methods. Thousand Oaks, CA: Sage Publications.

Pitti, I. (2019). Being women in a male preserve: An ethnography of female football ultras. Journal of Gender Studies, 28(3), 318-329. DOI: 10.1080/09589236.2018.1443803.

Pope, S. (2012). "The Love of My Life”: The meaning and importance of sport for female fans. Journal of Sport and Social Issues, 37(2), 176-195. DOI: 10.1177/0193723512455919.

Pope, S., \& Kirk, D. (2014). The role of physical education and other formative experiences of three generations of female football fans. Sport, Education and Society, 19(2), 223-240. DOI: 10.1080/13573322.2011.646982.

Sveinson, K., \& Hoeber, L. (2016). Female sport fans' experiences of marginalization and empowerment. Journal of Sport Management, 30(1), 8-21. DOI: 10.1123/jsm.2014-0221

Talimciler, A. (2017). Futbol taraftarlığındaki erkeklik imgesi. Sosyal ve Beşeri Bilimler Dergisi, 1(1), $27-57$.

Tracy, S. J. (2013). Qualitative Research Methods. UK: Wiley-Blackwell.

Toffoletti, K. (2014). Iranian women's sports fandom: gender, resistance, and identity in the football movie offside. Journal of Sport and Social Issues, 38(1), 75-92. DOI: 10.1177/0193723512468758.

Ussher, J. (1997). Fantasies of femininity: Reframing the boundaries of sex. London, UK: Penguin Books.

Wacquant, L., \& Bourdieu, P. (2014). Düşünümsel bir antropoloji için cevaplar. Çev.: Nazlı Ökten, İstanbul: İletişim Yayınları.

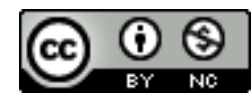

Bu eser Creative Commons Atıf-Gayri Ticari 4.0 Uluslararası Lisansı ile lisanslanmıştır. 